\title{
Максим СКОРОХОДОВ
}

\section{СЕРГЕЙ ЕСЕНИН В ЗЕРКАЛЕ АМЕРИКАНСКОЙ ПЕРИОДИЧЕСКОЙ ПЕЧАТИ 1922-1925 ГОДОВ*}

Аннотация: Несмотря на наличие значительного числа исследований, посвященных анализу работ о С.А. Есенине проживавших в США критиков, мемуаристов и ученых, далеко не полностью выявлены и введены в научный оборот газетные и журнальные публикации, характеризующие жизнь и творчество русского поэта. В статье рассматриваются материалы на идише, английском и испанском языках, опубликованные в Соединенных Штатах в 1922-1925 гг. Наиболее часто о Есенине писали в следующие периоды: во время его совместной с А. Дункан поездки по Соединенным Штатам (октябрь 1922 - февраль 1923 года), их пребывания в Европе (февраль - июль 1923 года), в первые дни после его трагической гибели (декабрь 1925 года), а затем - в откликах на смерть Дункан (сентябрь 1927 года). Значительный интерес представляет вводимый в научный оборот материал «Some Bolshevistic Troubadours», написанный известным американским переводчиком, редактором и журналистом Натаном Доулом. В рецензию Доула включены большие фрагменты маленьких поэм Есенина, переведенные им на английский язык, а книга русского поэта «Триптих» характеризуется как «красная рапсодия».

Ключевые слова: Сергей Есенин, Айседора Дункан, Натан Доул, Джон Клейтон, Джордж Селдс, периодические издания США, биография, творчество.

() 2017 Максим Владимирович Скороходов (кандидат филол. наук, ст. научный сотрудник, Институт мировой литературы им. А.М. Горького РАН, Москва) msk2002@ rambler.ru

* Исследование выполнено за счет гранта Российского научного фонда (проект № 14-18-02709) и в ИМЛИ РАН. 


\title{
Maxim SKOROKHODOV
}

\section{SERGEI ESENIN IN THE MIRROR OF AMERICAN PERIODICALS, 1922-1925}

\begin{abstract}
Despite a vast amount of the studies by American critics, memoirists and scholars devoted to the analysis of Sergei Esenin's works, not all the pieces of the American press on the life and work of the Russian poet have been introduced into scientific use. The article considers materials on Esenin in Yiddish, English and Spanish, published in the United States in 1922-1925. Most often the American press wrote about Esenin in the following periods: during his trip with Isadora Duncan to the United States (October 1922 - February 1923), during their stay in Europe (February - July 1923), just after Esenin's tragic death (December 1925), and after Isadora Duncan's death (September 1927). The article Some Bolshevistic Troubadours by a well-known American translator, editor and journalist Nathan Dole is of a special interest, and is introduced into scientific use. Dole included in his review large fragments of Esenin's poems, translated into English and called Esenin's book Triptych "a red rhapsody".

Key words: Sergei Esenin, Isadora Duncan, Nathan Haskell Dole, John Clayton, George Seldes, US periodicals, biography, creativity.
\end{abstract}

(C) 2017 Maxim V. Skorokhodov (PhD, Senior Researcher, A.M. Gorky Institute of World Literature, Russian Academy of Science, Moscow) msk2002@ rambler.ru 
С.А. Есенин вместе со своей супругой, известной танцовщицей Айседорой Дункан провел в Америке около четырех месяцев - 1 октября 1922 года океанский лайнер «Paris» (недавно было уточнено время отплытия лайнера из Европы - см.: [Скороходов 2013]), на борту которого они путешествовали, вошел в американские территориальные воды, а 3 февраля 1923 года начался их путь из Нью-Иорка в Европу. Эти месяцы стали периодом наиболее интенсивной публикации материалов с упоминанием поэта, которого рассматривали как молодого русского мужа талантливой американки. Последующие периоды частых упоминаний Есенина приходятся на время его пребывания в Европе в феврале - июле 1923 года, на дни после его трагической гибели в декабре 1925 года, а также связаны с многочисленными откликами на смерть в сентябре 1927 года Дункан.

Однако о поэте писали в Соединенных Штатах и в другие годы. Появилось немалое число исследований, рассматривающих восприятие Есенина американцами. Прежде всего, необходимо назвать работу Гордона Маквея "Isadora \& Esenin" [McVay 1980], в которой в научный оборот введен значительный пласт материалов периодики. Недавно Маквей безвозмездно передал свой ценнейший архив России - в Государственный музей-заповедник С.А. Есенина на родине поэта. К настоящему времени выполнено общее описание полученных материалов [Иогансон 2017], архив требует дальнейшего изучения.

Некоторые материалы о Есенине на английском языке, в том числе опубликованные в Соединенных Штатах, характеризовались в работах О.И. Юшиной, в том числе в ее диссертации [Юшина 1981]. Краткий обзор «Есенин в англоязычном литературоведении» выполнен в 2008 году А.Ю. Большаковой [Большакова 2008]. Переводы фрагментов публикаций американской периодики о Есенине вошли в «Летопись жизни и творчества С.А. Есенина», они относятся как ко времени жизни поэта в Америке, так и к более поздним годам [Летопись 2008; Летопись 2010; Летопись 2013]. Значительный пласт материалов будет введен в научный оборот в разделе «Дополнения» второй книги пятого тома «Летописи жизни и творчества С.А. Есенина», выпуск которой намечен на 2018 год.

Характеристика рецепции жизни и творчества Есенина в разных странах, в том числе в США, содержится в монографии Н.И. Шубниковой-Гусевой [Шубникова-Гусева 2012]. Американские контексты есенинского творчества рассматриваются в кандидатской диссертации Н.А. Еременко [Еременко 2015]. Среди публикаций последнего времени, вводящих в научный оборот материалы американской прессы 1920-х годов, отметим работу Е.Ю. Коломийцевой [Коломийцева 2014]. 
Выходившая в Соединенных Штатах пресса русского зарубежья, писавшая о поэте, изучена значительно лучше [Русское зарубежье 1993; Скороходов, Коломийцева 2015; Скороходов, Коломийцева 2016], чем издания на других языках. Исследователи англоязычных американских изданий, дававших оценки есенинского творчества, были названы выше. Однако о Есенине писали и газеты, выходившие на других языках. К сожалению, не все они просмотрены. Поисковую работу в значительной степени упрощает наличие электронных копий изданий, однако вследствие плохой сохранности газет и журналов далеко не все отсканированные тексты верно распознаны. К тому же еще не вся периодика оцифрована и доступна для исследователей.

Ниже характеризуется ряд опубликованных в Соединенных Штатах материалов, посвященных Есенину, которые ранее лишь кратко упоминались либо и вовсе не введены в научный оборот. Ряд из них в переводе на русский язык будет процитирован в упоминавшейся выше второй книге пятого тома «Летописи жизни и творчества С.А. Есенина».

Для исследователей жизни и творчества поэта наибольший интерес представляют критические статьи и обзоры, авторы которых рассматривают Есенина в контексте развитий русской и мировой литературы. Такие материалы зафиксированы в томах есенинской летописи. Среди выявленных в последнее время американских материалов подобного рода - статья Е. Извольской, впервые опубликованная на французском языке [Коломийцева, Скороходов 2014].

Одно из наиболее ранних упоминаний Есенина в статьях англоязычной американской периодики, посвященных рассмотрению русской литературы, содержится в нью-йоркском журнале "The Living Age" за 11 марта 1922 года. В разделе "Life, letters, and the arts" помещен материал "A Russian on Russian literature", который открывается абзацем с упоминанием Есенина и его соавторов по сборнику «Скифы» - А.А. Блока и Андрея Белого:

Criticism of the morbidity and gloom of Russian literature has long been familiar in America, nor have the literary developments of the Bolshevist regime - striking as they have been - overcome the critics. The wild mysticism of Byelii and Essenin, the "Scythian" doctrine of Blok, seem to the American mind almost as morbid as the profound gloom of the earlier novelists.

Особого внимания заслуживает опубликованная в газете "New York Times" 25 февраля 1923 года запоздалая рецензия Н. Доула (Nathan Haskell Dole) «Певцы большевизма» ("Some Bolshevistic Troubadours") - отклик на вышедшие в 1920-1921 гг. в Берлине 
книги издательства «Скифы», в числе которых «Триптих» Есенина, а также на выпущенный в 1921 году в стокгольмском издательстве «Северные огни» сборник «К новым далям. Лирика нежных созвучий».

Натан Доул (1852-1935) - известный американский поэт, редактор, журналист, активный участник различных творческих объединений. Он имел широкий круг общения, включавший известных писателей его времени (а прожил он большую, насыщенную событиями жизнь): Генри У. Лонгфелло, У. Каллена Брайанта, Уолта Уитмена, Уильма Дина Хоуэллса, Джона Г. Уиттьера, Томаса Уэнтворта Хиггинса, Эдварда Эверетта и др.

Дом Доула в Бостоне, в котором он проживал с 1892 по 1928 год, длительное время был местом встречи музыкантов и литераторов. Вероятно, Доул присутствовал на выступлениях А. Дункан в бостонском Symphony Hall в октябре 1922 года, на которых был и Есенин. Сведения об их встречах и общении не выявлены. Отметим, что Доул обратился к рассмотрению книг русских авторов спустя два года после их выхода в свет, причем именно в то время, когда американская пресса активно публиковала материалы о Есенине: в начале февраля 1923 года американские газеты сообщали об отъезде Дункан и ее молодого мужа из Америки в Европу, а затем печатали заметки, связанные с их семейными ссорами, и сообщения о вероятном расставании супругов. Не исключено, что такой информационный фон привлек внимание Доула к есенинскому творчеству. В его довольно пространной рецензии разбору есенинских текстов уделяется более трети общего объема, хотя в поле зрения критика оказываются и другие яркие произведения рубежа 1910-1920-х годов: «Скифы» и «Двенадцать» А.А. Блока, «Христос Воскресе» Андрея Белого, «Избяные песни» Н.А. Клюева.

Доул широко известен как переводчик с испанского и французского языков. Переводил он и русских писателей, включая Л.Н. Толстого. Так, в 1886 году им выполнен первый перевод на английский язык «Анны Карениной». В предисловии к переводу Доул утверждал, что переводил с русского оригинала, лишь иногда соотнося свой вариант с уже имевшимся в то время переводом на французский язык. Однако первые рецензенты отмечали некоторые сокращения текста романа, допущенные Доулом, что, по их мнению, свидетельствовало о его ориентации именно на французский источник ${ }^{1}$. Для нас же в данном случае важно, что уже в середине 1880-х годов Доул настолько хорошо владел русским языком, что перевел объемный роман Толстого.

В числе книг Доула — "Young Folks History of Russia" (1881), "The Latin Poets" (1905), "The Greek Poets" (1907), "Life of Count

\footnotetext{
${ }^{1}$ Подробнее см.: [Birdwood-Hedger 2006: 71-74].
} 


\section{Some Bolshevistic Troubadours}

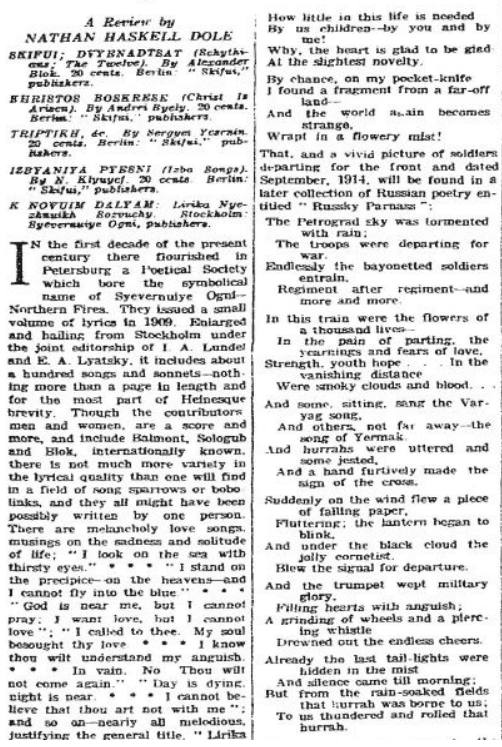

Рецензия Н. Доула на книги издательств «Скифы» и «Северные огни»."New York

Times", 25 февр. 1923 г. (фрагмент)
Tolstoi” (1911). Доул работал в таких изданиях как "Boston Evening Transcript", "The Portland News", "The Independent", "The New York Times".

Рецензия Доула начинается с содержащего неточности рассказа об основанном Е.А. Ляцким акционерном издательском обществе «Огни», которое в последующем было возобновлено в Стокгольме как издательство «Северные огни». Называя имена К.Д. Бальмонта, Ф.К. Сологуба и А.А. Блока, Доул отмечает:

But what makes them particularly interesting is that several of the authors represented have become notorious for their emergence into the arena of futurism. It is much the same as if gentle, pensive painters of the Hudson River school suddenly kicked over the traces and joined the ranks of F.T. Marinetti, or as it quiet Mendelssobnians became imbued with the vibrations of the Intonarumori futurtsti or Luigi Russolo, Alexander Blok, for instance.

В рецензии Доула немало переведенных на английский язык стихотворных текстов. Так, после процитированных рассуждений он дает полный перевод стихотворения Блока «Оставь меня в моей дали...».

Отметив: «That, and a vivid picture of soldiers departing for the front and dated September, 1914, will be found in a later collection of Russian poetry entitled "Russky Parnass"», - Доул дает почти полный перевод стихотворения Блока «Петроградское небо мутилось дождем...».

Рецензент высоко оценивает два приведенных стихотворения, считая их важными для понимания более позднего творчества Блока:

These two poems, even in the slag-form of a literal translation, mark an advance from the sentimental outpourings of Blok's twenties; but the latest 
manifestations of his genius - for it was genius - are certain to elicit quite opposite judgments, Ivanof-Razumnik, for instance, in a long and somewhat repetitions introduction to the little volume containing Blok's "Scythians" and "The Twelve" declares that they "will live for decades and decades in Russian literature"...

В контексте анализа произведений сформировавшейся в 1917 году литературной группы «Скифы» и одноименных сборников Доул впервые в своей рецензии упоминает Есенина:

Conservatives, on the other hand, do not spare epithets in condemning what seems to them gross vulgarity, outrageous blasphemy. Take the symbolism that characterizes not only these later poems of Blok, but many of the others contained in the volumes above noted; it is the symbolism of the Church, but diverted or perverted entirely from its historic import. It seems singular that these three revolutionary poets, Blok. Byely and Yesenin, should with one accord take the Resurrection of Christ to stand for the restoration of the Russian people after its crucifixion and temporary entombment.

Доул характеризует образную систему и символику поэмы «Двенадцать», приводит небольшую цитату и показывает, что внимание к образу Христа сближает творческие поиски 19171918 годов Блока, Белого и Есенина. Однако у каждого из этих авторов есть особенности в понимании как этого образа, так и путей развития христианства в революционные годы.

Движение Запада на Восток рецензент иллюстрирует пространной цитатой из блоковских «Скифов», которая завершается последней строфой:

В последний раз - опомнись, старый мир!

На братский пир труда и мира,

В последний раз на светлый братский пир

Сзывает варварская лира!

Затем, без какого-либо перехода, Доул обращается к Есенину, которого характеризует как мужа Айседоры Дункан, вместе с супругой только что посетившего Америку и направляющегося теперь в свою «Инонию». Рецензент отмечает, что для поэтики Есенина характерен «псевдохристианский или пародийно-христианский (?) символизм» ("pseudo-Christian, mock-Christian — ? symbolism”). Эволюцию есенинского творчества Доул рассматривает в контексте происходящих в России событий:

It would undoubtedly shock conservatism. But, if one is willing to admit that Russian Communism may be seriously accepted not as a mere belief but as a matter of life and death Orthodox Christianity, especially as developed $\mathrm{m}$ Russia, may in the eyes of such persons deserve to be pilloried. 
Рецензент цитирует пятую главу «Деяний святых апостолов», ссылки на которую, по его мнению, используются в России для оправдания борьбы с контрреволюцией. Как известно, Анания и его жена Сапфира, пытавшиеся обмануть апостолов, были наказаны за этот грех смертью. «И великий страх объял всю церковь и всех слышавших это» (Деян. 5:11). В контексте своих рассуждений Доул рассматривает «Инонию», в начале которой Есенин провозглашает себя пророком. Доул приводит довольно большие фрагменты «Инонии» и дает англоязычному читателю общее представление об этом произведении, которое вызвало широкий отклик критики.

Характеризуя книгу Есенина «Триптих» как «красную рапсодию», в которую вошли лирические миниатюры - «Пришествие», «Октоих», «Преображение», рецензент предлагает с серьезностью относиться к есенинским текстам, какая бы символика не оказывалась в них преобладающей - христианская либо древнеегипетская: «Let us treat it in all seriousness, even when he reverts from his Christian symbolism to that of the ancient Egyptians».

Процитировав первую и вторую главки маленькой поэмы Есенина «Преображение», автор замечает:

He calls on his Russians, "Huntsmen of the Universe", "Sweeping the heavens with the net of the Dawn" to blow the trumpets. He declares that "The Sun, like a cat, from the heavenly willow, with his paw of gold" touches his hair. And the Heavenly Guest will come.

Здесь довольно точно переданы есенинские образы: «ловцы вселенной», которые «неводом зари» зачерпнули небо, солнце, которое «как кошка, / С небесной вербы / Лапкою золотою» касается волос.

Доул высоко оценивает есенинское творчество, отмечая удачные рифмы, искреннюю взволнованность человека, который пророчески предсказывает счастье если и не всему миру, то по крайней мере своей родине:

Through its incoherence, in spite of its almost haphazard misuse of words, there is, especially in the original, often cleverly rhymed, a thrill as if the man were in reality a prophet, for he predicts a happier world, at least a happier homeland.

И в подтверждение проводит строки из первой и второй главок маленькой поэмы «Октоих».

Писал о Есенине и другой известный американский журналист - Джордж Селдс (George Seldes; 1890-1995). Он, выходец из семьи еврейских эмигрантов из России, принадлежал к числу тех журналистов, которых называли макрейкерами (muckrakers), или «разгребателями грязи», поскольку они уделяли первостепенное 
внимание выявлению негативных сторон жизни современного им общества - подтасовка фактов, коррупция, различные злоупотребления. В первой половине 1920-х гг. Селдс был европейским корреспондентом “Chicago Daily Tribune”.

Эта газета 17 февраля 1923 года публикует заметку Селдса «Сергей покидает Айседору ради дикой России» (“Serge quits Isadora for Russia Wild") — отклик на инцидент с участием Есенина в парижском "Hotel de Crillon" и его последствия [Летопись 2008, с. 291-299].

15 декабря 1924 года “Chicago Daily Tribune” печатает материал Селдса «Сонный муж, или Развод красных супругов отменяется» ("Husband Too Sleepy; Ruins Red Divorce"). В него вошло блиц-интервью с Дункан, в котором упоминается Есенин. Заявляя, что «Айседора Дункан совершенно сломлена» ("Isadora Duncan is broken”), журналист сообщает, что танцовщица находится в бедственном положении - у нее нет средств не только для арендных платежей, но и для питания, она не знает, где будет жить на следующей неделе. Для улучшения своего материального положения она планирует опубликовать имеющиеся у нее 1000 любовных писем. Перевод этого материала на русский язык две недели спустя, 28 декабря 1924 года, появится в русской эмигрантской газете - парижских «Последних новостях» (в нем содержится и та информация, которая не вошла в рассматриваемый английский вариант - вероятно, использовались и другие источники). Текст из «Парижских новостей» приведен в «Летописи жизни и творчества С.А. Есенина» [Летопись 2010, с. 513-514]. Здесь же даем оригинальный текст интервью:

When asked about the love letters, Mlie. Duncan said:

- I have no hesitancy about them. Ever since I got into trouble I found out that I have no friends. Nobody sticks to you when you are in difficulties, so why should I hesitate about publishing these letters? They are going to ruin a lot of families, but why should I worry?

\section{Husband to Be a Bandit}

- Where is your husband, Yessenin? - she was asked.

- $\mathrm{O}$, Serge has gone into the Caucasus, he wrote me, to become a bandit. He writes he is going to be a robber to get thrills. He wants to write poetry about robbery and wants experience as a bandit.

In order to get a soviet divorce it is necessary to file your application before 12 o'clock, noon, so you can get the divorce in the afternoon, but it was impossible to get Serge to appear at the divorce commissariat at noon. He was always asleep after the night out.

\section{Cannot Get French Visa}

- Now, while I do not consider myself married to Yessenin, because America does not recognize soviet marriages, France does recognize soviet 
marriage and France refuses to give me a visa on a bolchevik passport to go to Paris and sell my two houses, which are worth a lot of money.

Любопытные рассуждения Есенина об американцах содержатся в неподписанном материале "A poet's soul in America", появившемся в "Chicago Daily Tribune" 19 февраля 1923 года. Сообщается, что «большевистский поэт» (“the bolshevist poet”) Есенин, которому американцы не понравились, выделяет четыре типа жителей страны:

He says now that there have been four generations of Americans, the pioneers, the workers who followed them and created the wealth, the snobs who followed them, and now a generation of legalized commercial thieves.

Эти суждения близки тем, которые появятся в очерке поэта «Железный Миргород», написанном им вскоре после возвращения в Россию. Есенин отметит:

Что такое Америка?

Вслед за открытием этой страны туда потянулся весь неудачливый мир Европы, искатели золота и приключений, авантюристы самых низших марок, которые, пользуясь человеческой игрой в государства, шли на службу к разным правительствам и теснили коренной красный народ Америки всеми средствами.

[...] Сами американцы - народ тоже весьма примитивный со стороны внутренней культуры.

Владычество доллара съело в них все стремления к каким-либо сложным вопросам. Американец всецело погружается в "Business" и остального знать не желает [Есенин 1997, с. 167, 170].

Рассматриваемая заметка в "Chicago Daily Tribune" заканчивается сожалениями по поводу того, что американский народ не смог произвести на Есенина благоприятного впечатления:

We regret that the American people failed to make a favorable impression on this poet. Our parlor bolsheviki should have protected him while he was here. We'll admit that a sweet poetic soul like Serge's ought not to go unchaperoned among a people lacking wholly, as Serge explains, in appreciation of art. Greenwich Village ought to send him an apology.

После уже упоминавшегося происшествия в парижском Hotel de Crillon Есенин покинул город и в сопровождении служанки Дункан уехал в Берлин. В связи с этим в прессе начали появляться различные слухи, в том числе о том, что брак Есенина и Дункан распался. Чтобы прояснить ситуацию представитель "Chicago Tribune Foreign News Service” Джон Клейтон (John Clayton) 2 марта 1923 года встречается в Берлине с Есениным и берет у него интервью. Результатом беседы явилась публикация в “Chicago Daily 
Tribune” 3 марта материала «Сергей поет серенады своей дорогой Айседоре» ("Serge yodels love lyrics to darling Isadora").

Поскольку сохранилось крайне мало интервью с Есениным, приведем данный материал полностью:

BERLIN, March 2. - Distance lends enchantment to view, and Serge Yessenin again sings love lyrics of Isadora.

The temperamental Russian poet visited The Tribune office today to complain that he did not remember saying anything about his new wife and that he loved Isadora better than anything in the whole world, and that he wanted to fight a duel with The Tribune correspondent, and that anyway it is all wrong, because Isadora is coming to Berlin. He is living with his son.

When The Tribune correspondent suggested that perhaps Serge was under the influence of hooch he replied that he was very tired from his trip.

\section{Isadora Wires Complaint}

Serge's visit was prompted by a telegram from Isadora justly complaining against Yessenin's tirade. Serge's memory of the evening following his arrival from Paris is exceedingly defective. He recalls his arrival at the station, a short taxi ride and his conversation with The Tribune, but the details are all vague and hazy. The tired genius often has a lapse of memory.

At any rate, Serge asks The Tribune to publish the following open letter:

"1. I am only separated temporarily from Isadora Duncan in order to arrange my business affairs in Berlin.

2. I love Isadora Duncan better than anything in the world.

3. There is no other woman in my life. On my trip my new wife did not accompany me, hut her maid came with me in order to help me because orientation is very hard in Europe for me."

\section{Greeting America, Too}

He added a greeting for America.

- In America I did not dare say I was a bolshevist, - he volunteered, - but here I am free to speak.

He paused as if the fate of empires hung upon his words.

- I am a bolshevist.

Yessenin explained that he will remain in Berlin to publish a newspaper.

Как видим, Есенин крайне корректно по отношению к Дункан охарактеризовал ситуацию и признался в любви к танцовщице. Это официальное заявление поэта не корреспондировалось с теми довольно многочисленными публикациями, в которых сообщалось о семейных скандалах, рукоприкладстве, предстоящем расставании супругов. Вероятно, представители других изданий не стали перепечатывать или давать в изложении этот материал, в то время как информация о скандалах с участием Есенина быстро разлеталась по различным европейским и американским газетам. В связи с этим какие-либо упоминания о данном интервью не были обнаружены составителями «Летописи жизни и творчества С.А. Есени- 
на» при фронтальном просмотре хранящейся в фондах отечественных архивов и библиотек периодики. Впрочем, вероятно, беседе в европейском представительстве "Chicago Daily Tribune" предшествовал и другой шаг Есенина к примирению с Дункан об этом свидетельствует краткая информация в номере нью-йоркской русскоязычной газеты «Новое русское слово» от 1 марта 1923 года: «Поэт Есенин примирился с Айседорой Дункан, послав ей телеграмму с комплиментами» [Летопись 2008, с. 312]. Есенин и Дункан встретятся лишь месяц спустя [Летопись 2008, с. 338339]. Однако месяц, проведенный Есениным в Берлине в разлуке с Дункан, был довольно насыщенным - поэт завершает подготовку к изданию книги «Стихи скандалиста», пишет предисловие к ней, выступает на литературных вечерах. То есть Есенина действительно, как он и сообщает в открытом письме, ждали в Берлине дела.

Американские издания откликались на различные события в жизни Есенина, что в значительной степени было обусловлено предпочтениями читательской аудитории конкретного издания.

Например, выходившая в Цинциннати (шт. Огайо) газета "American Israelite" напечатала 29 ноября 1923 года анонимную заметку «Муж Айседоры Дункан “высказался” об евреях» (“Isadora Duncan's husband 'discussed' Jews") - в материале по статье Л.С. Сосновского «Испорченный праздник», опубликованной в московской «Рабочей газете», излагался эпизод в пивной И.А. Малинникова с участием Есенина ${ }^{2}$.

Выше уже было отмечено, что резкий рост числа упоминаний Есенина в американской печати вызвала его трагическая гибель. В те дни публиковались как краткие информационные материалы, так и более пространные статьи, дававшие общее представление о жизни Есенина, при этом основное внимание уделялось не творчеству поэта, а его путешествию по Европе и Америке с Дункан, а также некоторым эпизодам, которые рассматривались как скандальные. Например, газета "Chicago Daily Tribune" в номере от 29 декабря 1925 года напоминала читателям о том, что, когда в октябре 1922 года мисс Дункан прибыла в Нью-Йорк со своим молодым русским мужем Есининым, им был запрещен въезд в Соединенные Штаты, а позже танцовщица появлялась на сцене разных американских городов, завернувшись в красный флаг; в результате в нескольких местах ей было запрещено танцевать, и в феврале следующего года она вернулась с мужем в Европу. Также сообщается, что в Москве Есенин, обвиненный в критике советского режима, был отправлен в тюрьму, что не соответствует действительности.

\footnotetext{
${ }^{2}$ См. об этом: [Летопись 2010, с. 136-137].
} 
Откликнулись на гибель Есенина и еврейские газеты Америки. Так, 29 декабря 1925 года бостонская газета "Forward", печатавшаяся на идише, поместила неподписанный материал «Юный большевистский поэт Сергей Есенин, разведенный муж Айседоры Дункан, покончил с собой в Ленинграде». После заглавия приводится аннотация: «Вскрыл себе вены и затем повесился. - Оставил записку, написанную собственной кровью. - Был величайшим поэтом у большевиков, однако был более безумцем, чем поэтом. - Айседоре Дункан пришлось с ним развестись из-за его диких выходок».

В начале статьи сообщается:

Сергей Есенин, юный русский поэт, который был женат на знаменитой танцовщице Айседоре Дункан, покончил с собой в Ленинграде. Он разрезал себе вены на руках и затем повесился. Нашли записку, которую он написал своей кровью, но содержание невозможно прочесть. Не так давно Есенин женился на Софье Толстой, внучке знаменитого писателя Льва Толстого. Умерший в последнее время страдал от нервного расстройства.

Есенин знаменит, как величайший большевистский поэт. Он сын крестьянина, и в своих стихотворениях постоянно воспевает крестьянскую жизнь, плуг, лошадь, землю и, естественно, революцию. Ему было всего 27 [в действительности 30. - M.С.] лет.

Далее, как и во многих подобных материалах, даются подробности о взаимоотношениях Есенина и Дункан. Есть и отличие издание на идише упоминает о конфликтах, возникавших у Есенина с представителями еврейской общины Америки:

Когда он был в Нью-Йорке, группа еврейских писателей в доме Мани Лейба устроила для него банкет. Он напился и начал оскорблять их отборными словами. Он был так пьян, что его пришлось связать [и удерживать так] до тех пор, пока он не протрезвел. Его арестовывали за антисемитские высказывания ${ }^{3}$.

Отметим, что отношения Есенина с еврейским американским поэтом и переводчиком Мани Лейбом были неровными. Исследователь жизни и творчества Мани Лейба В.А. Дымшиц, комментируя поэму еврейского поэта «Строки Есенина», посвященную памяти русского поэта и написанную ориентировочно в 1930-е годы, справедливо отмечает:

Мани Лейб переводил стихи Есенина на идиш еще до приезда русского поэта в США. В 1923 году Есенин во время своего визита в Нью-

${ }^{3}$ Перевод с идиша на русский язык выполнен В.А. Дымшицем для второй книги пятого тома «Летописи жизни и творчества С.А. Есенина». Выражаю искреннюю признательность В.А. Дымшицу за оказанное содействие. 


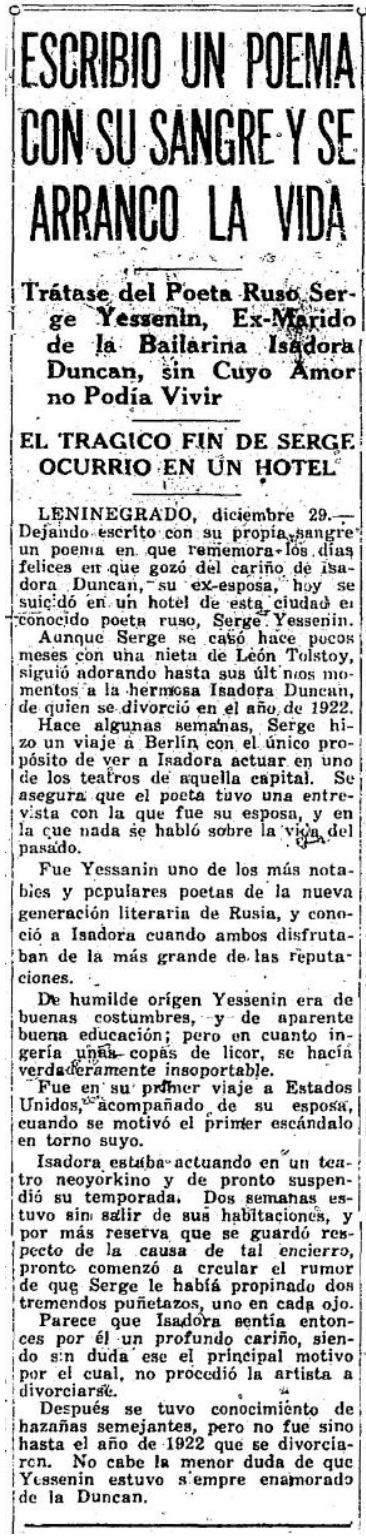

Колонка газеты "El Heraldo de Мexico" 30 дек. 1925 г.
Йорк познакомился и подружился с Мани Лейбом. Несмотря на то, что их отношения складывались не всегда гладко (о чем есть мемуарные свидетельства), Есенин в своих путевых заметках о США «Железный Миргород» очень высоко оценивает творчество Мани Лейба [Бумажные мосты 2012, с. 155].

В другой своей статье В.А. Дымшиц пишет о том значительном влиянии, которое оказало есенинское творчество на поэтику еврейского автора:

В 1920-1930-х гг. творчество Мани Лейба находилось под сильным влиянием русских «новокрестьянских» поэтов, прежде всего Есенина и Клюева. Если в своей ранней, символистской поэзии он сознательно обедняет словарь, добиваясь «гармонического» звучания, то словарь его зрелых произведений очень богат, насыщен диалектизмами и конкретными деталями [Дымшиц 2010, с. 190].

На смерть Есенина отзывается и издававшаяся в Лос-Анджелесе испаноязычная газета "El Heraldo de Mexico". 30 декабря 1925 года в ней публикуется материал «Он написал стихотворение кровью и покончил с собой» ("Escribió un poema con su sangre y se arrancó la vida”) с краткой аннотацией перед текстом: «Русский поэт Сергей Есенин, бывший муж танцовщицы Айседоры Дункан не смог жить без ее любви" ("Trátase del Poeta Ruso Serge Yessenin, Ex-Marido de la Bailarina Isadora Duncan, sin Cuyo Amor no Podía Vivir"). Как явствует уже из заголовочного комплекса, Есенин рассматривается прежде всего как муж танцовщицы Дункан. Написанное кровью незадолго до смерти стихотворение ${ }^{4}$ интерпретируется как навеянное «воспоминаниями о счастливых днях, наполненных радостью люб-

${ }^{4}$ В заметке оно не названо. Имеется в виду стихотворение «До свиданья, друг мой, до свиданья...», которое поэт за сутки до гибели передал своему приятелю, поэту В.И. Эрлиху. 


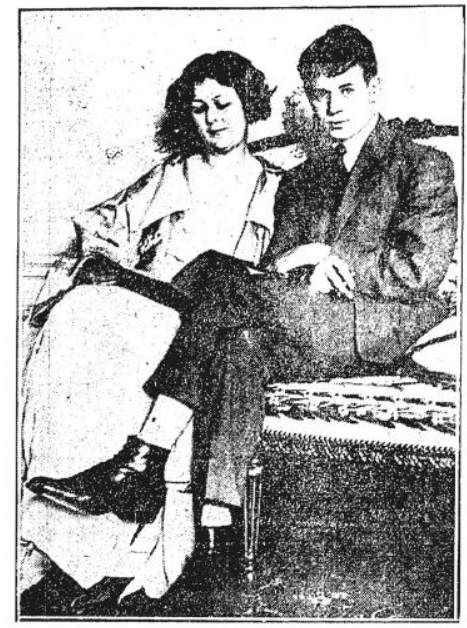

NOTED DANCER AND HUSBAND BARRED BY U.S. Isadora Duncan and her husband, Serge Yessinin, who were prevented from landing in New York by federal officials.

"Chicago Daily Tribune", 2-3 октября 1922 г. Фото Есенина и Дункан

ви к Айседоре Дункан». Впрочем, в материале речь идет не только об отношениях Есенина с Дункан, также сообщается о женитьбе поэта на внучке Л.Н. Толстого. Есенин характеризуется как один из наиболее самобытных и популярных поэтов, представляющих в России новое литературное поколение.

В американских газетах неоднократно публиковались фотографии Есенина и Дункан в сопровождении кратких текстов. Такие материалы начали появляться еще до приезда супругов в Соединенные Штаты. Например, 11 августа 1922 года - фотография в газете "Chicago Daily Tribune" с подписью: «Знаменитая танцовщица и ее русский муж. Айседора вместе с Есениным, который читает свои новые стихи. Вскоре они отправятся на Дальний Восток» ("FAMOUS DANCER AND RUSSIAN HUSBAND. Isadore [sic! - M.C.] Duncan is shown with Mr. Yesenin, reading some of the latter's works. They are soon to tour the Far East"). Источник информации о якобы предполагавшейся поездке Есенина и Дункан на Дальний Восток не выявлен.

Газета "Chicago Daily Tribune", как и многие другие американские издания, откликнулась на прибытие Есенина и Дункан в Америку. Среди материалов, посвященных супругам, - их фотография с подписью: «Знаменитой танцовщице и ее мужу запрещен въезд в США. Федеральные чиновники не позволили Айседоре Дункан и ее мужу Сергею Есенину сойти на берег в НьюЙорке» ("NOTED DANCER AND HUSBAND BARRED BY U.S. Isadora Duncan and her husband Serge Yessenin, who were prevented from landing in New York by federal officials"). Материал опубликован в номере от 2 октября 1922 года.

Позже Есенин отметит в очерке «Железный Миргород»:

Сотни кинематографистов и журналистов бегают по палубе, щелкают аппаратами, чертят карандашами и всё спрашивают, спрашивают и спрашивают. Это было приблизительно около 4 часов дня, а в $5 \frac{1}{2} 2$ нам принесли около 20 газет с нашими портретами и огромными статьями о нас [Есенин 1997, с. 164]. 
Порой фотографии с подписями, в которых кратко сообщалось о недопущении супругов в Нью-Йорк, появлялись в прессе не в дни после события, а значительно позже. В качестве примера приведем материал газеты "Detroit Free Press" от 15 октября 1922 года. Издание опубликовало фотографию Есенина и Дункан с довольно пространной подписью:

Isadora Duncan, famous American dancer, and Serge Yessenin, her Russian poet-husband, who were permitted to land in this country October 2, after being detained 24 hours on Ellis Island. The detention by the New York immigration officials was to determine whether Yessenin is a courier of the soviet government.

В газете "Chicago Daily Tribune" 16 февраля 1924 года бы-

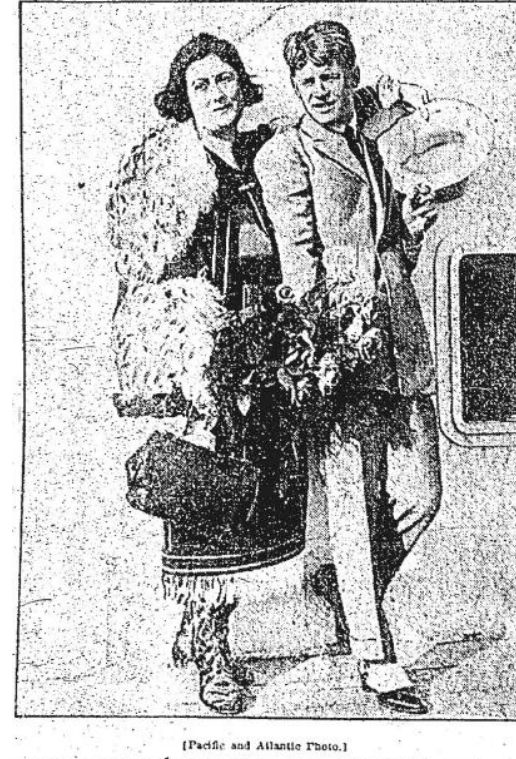

CLASSIC DANCER DIVORCED BY SOVIET. Isadora Duncan, who was separated from young poet-husband, Serge Yessinin, under Russian law.

“Chicago Daily Tribune”, 16 февр. 1924 г. Фото Есенина и Дункан ла помещена фотография супругов с подписью: “CLASSIC DANCER DIVORCED BY SOVIET. Isadora Duncan, who was separated from young poet-husband, Serge Yessinin [sic! - M.C.], under Russian law". В той же газете 30 декабря 1925 года появится фотография супругов с подписью: "ISADORA DUNCAN'S FORMER HUSBAND KILLS SELF. Sergin Yessinin [sic! - M.C.], Russian poet, who committed suicide, and the noted dancer, who divorced him a year ago".

Упоминания Есенина в статьях, появившихся в первые дни после гибели Дункан, не содержат существенно новых сведений о поэте, в связи с этим мы не рассматриваем их в данной работе.

Обращение к материалам периодической печати позволяет прояснить, какие именно аспекты жизни и творчества русского поэта в большей степени интересовали читателей. Данный материал актуален в связи с подготовкой второй книги пятого тома «Летописи жизни и творчества С.А. Есенина» - фундаментального научного исследования, в котором отмечаются основные упоминания Есенина в различных публикациях на русском и иностранных языках. 


\section{ЛИТЕРАТУРА}

[Большакова 2008] - Большакова А.Ю. Есенин в англоязычном литературоведении // Есенин и мировая культура. М.-Константиново-Рязань: Пресса, 2008. С. 118136.

[Бумажные мосты 2012] - Бумажные мосты: Пять еврейских поэтов: Мани Лейб, М.-Л. Галперн, Г. Лейвик, 3. Ландау, И. Мангер. СПб.: Издательство Европейского университета в Санкт-Петербурге, 2012.

[Дымшиц 2010] - Дымшии В.А. Мани Лейб. Нежин // Новое литературное обозрение. 2010. № 102. С. 183-194.

[Еременко 2015] - Еременко Н.А. Американская тема в творчестве С.А. Есенина: поэтика и контекст: Дис. ... канд. филол. наук. М., 2015.

[Есенин 1997] - Есенин С.А. Полное собрание сочинений: В 7 т. (9 кн.). Т. 5. М.: Наука; Голос. 1997.

[Иогансон 2017] - Иогансон Б.И. Мировая есениниана в фондах Государственного музея-заповедника С. А. Есенина (архивы Ю.Л. Прокушева и Г. Маквея) // Сергей Есенин. Личность. Творчество. Эпоха. Часть II. М. - Константиново - Рязань: ГМЗ С.А. Есенина, 2017. 31-42.

[Коломийцева 2014] - Коломийцева Е.Ю. Айседора Дункан и Сергей Есенин в Бостоне (по материалам газеты «The Boston Herald») // Современное есениноведение. 2014. № 28. C. $28-37$.

[Коломийцева, Скороходов 2014] - Коломийцева Е.Ю., Скороходов М.В. Из наследия Е. Извольской (Франция). Большевистские поэты-мистики // Современное есениноведение. 2014. № 28. С. 7-28.

[Летопись 2008] - Летопись жизни и творчества С.А. Есенина: В 5 т. (7 кн.). Т. 3. Кн. 2. М.: ИМЛИ РАН, 2008.

[Летопись 2010] - Летопись жизни и творчества С.А. Есенина: В 5 т. (7 кн.). Т. 4. М.: ИМЛИ РАН, 2010.

[Летопись 2013] - Летопись жизни и творчества С.А. Есенина: В 5 т. (7 кн.). Т. 5. Кн. 1. М.: ИМЛИ РАН, 2013.

[Русское зарубежье 1993] - Русское зарубежье о Есенине: Воспоминания, эссе, очерки, рецензии, статьи / Вступ. ст., сост. и коммент. Н.И. Шубниковой-Гусевой, М.: ИНКОН, 1993. Т. 1-2.

[Скороходов 2013] - Скороходов М.В. Прибытие С.А. Есенина и А. Дункан в Америку (по архивным материалам) // Современное есениноведение. 2013. № 27. C. 16-23.

[Скороходов, Коломийцева 2015] - Скороходов М.В., Коломийцева Е.Ю. Есениниана русского зарубежья: эмигрантская газета «Новое русское слово» - к 25 -летию со дня смерти Есенина // Современное есениноведение. 2015. № 4 (35). С. 10-20.

[Скороходов, Коломийцева 2016] - Скороходов М.В., Коломийцева Е.Ю. Ньюйоркская газета «Русский голос» (1922-1923) о С.А. Есенине и А. Дункан // Современное есениноведение. 2016. № 1 (36). С. 17-26.

[Шубникова-Гусева 2012] - Шубникова-Гусева Н.И. «Объединяет звуком русской песни»: Есенин и мировая литература. М.: ИМЛИ РАН, 2012.

[Юшина 1981] - Юшина О.И. Поэзия С. Есенина в оценке современного зарубежного литературоведения и критики (США, Великобритания, Канада, Новая Зеландия). Дис. ... канд. филол. наук. М., 1981.

[Birdwood-Hedger 2006] - Birdwood-Hedger, M. Tension between Domestication and Foreignization In English-language translations of Anna Karenina. Dissertation ... of Doctor of Philosophy. Edinburgh, 2006.

[McVay 1980] — McVay, G. Isadora and Esenin. Ann Arbor, MI: Ardis, 1980. 


\section{REFERENCES}

Bol'shakova, A.Yu. "Esenin v angloyazychnom literaturovedenii." Esenin i mirovaya kul'tura. Moscow; Konstantinovo; Ryazan': Pressa Publ., 2008: 118-136.

Bumazhnye mosty: Pyat' evrejskih poehtov: Mani Lejb, M.-L. Galpern, G. Lejvik, Z. Landau, I. Manger. St-Petersburg: Evropejskogo universiteta v Sankt-Peterburge Publ., 2012.

Dymshic, V.A. "Mani Lejb. Nezhin.” Novoe literaturnoe obozrenie 102 (2010): 183194.

Eremenko, N.A. Amerikanskaya tema v tvorchestve S.A.Esenina: poehtika i kontekst: Diss. ... kandidatf filol. nauk. Moscow, 2015.

Esenin, S.A. Polnoe sobranie sochinenij: in 7 vols. (9 books). Vol. 5. Moscow: Nauka Publ.; Golos Publ., 1997.

Ioganson, B.I. "Mirovaya eseniniana v fondah Gosudarstvennogo muzeya-zapovednika S.A. Esenina (arhivy Yu.L. Prokusheva i G. Makveya)." Sergej Esenin. Lichnost'. Tvorchestvo. Ehpoha. Vol. II. Moscow; Konstantinovo; Ryazan': GMZ S.A. Esenina Publ., 2017: 31-42.

Kolomijtseva, E.Yu. "Aisedora Dunkan i Sergej Esenin v Bostone (po materialam gazety The Boston Herald)." Sovremennoe eseninovedenie 28 (2014): 28-37.

Kolomijtseva, E.Yu., Skorokhodov, M.V. "Iz naslediya E. Izvol'skoj (Francia). Bol'shevistskie poehty-mistiki." Sovremennoe eseninovedenie 28 (2014):7-28.

Letopis' zhizni i tvorchestva S.A. Esenina: in 5 vols. (7 books). Vol. 3. Book 2. Moscow: IMLI RAN Publ., 2008.

Letopis' zhizni i tvorchestva S.A. Esenina: in 5 vols. (7 books). Vol. 4. Moscow: IMLI RAN Publ., 2010.

Letopis' zhizni i tvorchestva S.A. Esenina: in 5 vols. (7 books). Vol. 5. Book 1. Moscow: IMLI RAN Publ., 2013.

Russkoe zarubezh'e o Esenine: Vospominaniya, ehsse, ocherki, recenzii, stat'i. Moscow: INKON Publ., 1993, vols. 1-2.

Skorokhodov, M.V. "Pribytie S.A. Esenina i A. Dunkan v Ameriku (po arhivnym materialam)." Sovremennoe eseninovedenie 27 (2013) 16-23.

Skorokhodov, M.V., Kolomijtseva, E.Yu. "Eseniniana russkogo zarubezh'ya: ehmigrantskaya gazeta Novoe russkoe slovo - k 25-letiyu so dnya smerti Esenina." Sovremennoe eseninovedenie 4 (35) (2015): 10-20.

Skorokhodov, M.V., Kolomijtseva, E.Yu. "N'yu-jorkskaya gazeta Russkij golos (1922-1923) o S.A. Esenine i A. Dunkan.” Sovremennoe eseninovedenie 1(36) (2016): 17-26.

Shubnikova-Guseva, N.I. "Ob'edinyaet zvukom russkoj pesni”: Esenin i mirovaya literatura. Moscow: IMLI RAN Publ., 2012.

Yushina, O.I. Poehziya S. Esenina v ocenke sovremennogo zarubezhnogo literaturovedeniya i kritiki (SShA., Velikobritaniya, Kanada, Novaya Zelandiya). Diss. ... kandidata filol. nauk. Moscow, 1981. 